\title{
Jolanta AMBROSEWICZ-JACOBS
}

Uniwersytet Jagielloński

jolanta.ambrosewicz-jacobs@uj.edu.pl

\section{SPOTKANIA Z ZAGEADĄ W POLSCE}

\section{ABSTRACT Encounters with the Holocaust in Poland}

Repressed memories remain active and their outcomes bring undesirable effects for education about the Holocaust. How can facts and events that have been repressed or dismissed from the individual and collective memory be reintegrated into social consciousness? When will the memory of the Holocaust in Poland become a shared, collective legacy for Poles? How can education about the Holocaust deal sensitively with the Polish national sense of martyrdom? This remains a crucial question for Polish society. Can memorial sites, museums, historians, writers, educational institutions and civic organizations in post-communist Poland create space where the voice of Jewish victims and second and third generations can be heard and where communities of memory can integrate? Or will Polish society continue to be characterized by rivalry between competing memories? These questions form the foundation of my empirical studies and trigger interest in the evaluation of existing educational programs. A qualitative research, namely a participant observation of the Forum for Dialogue among the Nations program 'School of Dialogue' in Warsaw, will attempt to answer the above questions.

Keywords: Holocaust, education about the Holocaust, memory of the Holocaust

Słowa kluczowe: Zagłada, Holokaust, edukacja o Holokauście, pamięć Zagłady

\footnotetext{
Współpraca w części dotyczącej raportu z obserwacji uczestniczącej w Warszawie - Szymon Beźnic.
} 
Polacy byli świadkami niewyrażalnej zbrodni, ale - jak dowodza badania w więsszości nie za bardzo ja zauważali w trakcie jej dokonywania, a potem nie za bardzo przejmowali się zniknięciem dziesięciu procent ludności Polski przedwojennej. Jak więc teraz przywrócić pamięć tego, co się tutaj, obok nas stato?

Maria Janion ${ }^{2}$

T ytuł mojego tekstu został sformułowany ostrożnie, gdyż proces odzyskiwania pamięci o Zagładzie w Polsce, pełen meandrów i wysp zarówno pamięci, jak i niepamięci, nie jest zakończony. Poddawany jest on wpływom polityki historycznej, a zatem nie podlega jeszcze ani pełnej kategoryzacji, ani systematyzacji. Barbara Engelking i Jacek Leociak w słowie „Od Autorów” w drugim wydaniu monografii getta warszawskiego dotknęli istoty spotkania ze światem, który w przestrzeni publicznej powojennej Polski został zburzony, zasłonięty i zapomniany: Jeśli chcemy ujrzeć ten zaginiony świat, musimy wydobyć go spod zwatów zapomnienia, obojętności i niewiedzy. Jedynym obszarem, gdzie można jeszcze odnaleźć mieszkańców getta wraz z ich domami i ulicami, z ich życiem, cierpieniem iśmiercia, jest miejsce w naszej pamięcỉ.

Kamieniem milowym rozwoju pamięci o Holokauście w świecie był transmitowany w mediach proces Adolfa Eichmanna, rozpoczęty 11 kwietnia 1961 r. Po raz pierwszy od zakończenia II wojny światowej Prokurator Generalny Izraela Gideon Hausner oddał głos świadkom i ocalałym, w przeciwieństwie do procesów norymberskich, w trakcie których skupiono się głównie na zbrodniach wobec państw na skutek wywołania wojny przez Niemcy. Polska, kraj-świadek Holokaustu ${ }^{4}$, a jednocześnie kraj-ofiara II wojny światowej, gdy świeża historia Zagłady oddaliła się, zaczął zmuszać do wyjazdu Żydów, którzy w większości cudem przeżyli w Związku Radzieckim ${ }^{5}$, rzadziej w Polsce, i byli pełnoprawnymi obywatelami państwa polskiego. Na przywracanie pamięci o historii i kulturze Żydów polskich trzeba było czekać do

2 M. Janion, Do Europy - tak, ale razem z naszymi umartymi, Warszawa 2000, s. 167.

3 B. Engelking, J. Leociak, Getto warszawskie. Przewodnik po nieistniejacym mieście, wyd. II zm., popr. i rozsz., Warszawa 2013, s. 11.

4 Przywołuję termin za: J.-Ch. Szurek, Między historią a pamięcia: polski świadek Zagtady, [w:] Zagtada Żydów. Pamięć narodowa a pisanie historii w Polsce i we Francji. Wybrane materiaty z kolokwium polsko-francuskiego, Lublin 22-23 stycznia 2004, red. B. Engelking i in., Lublin 2006, s. 173-183.

523 VIII 1939 r. został zawarty Pakt o nieagresji między Niemcami a ZSRR, zawierający tajny protokół dotyczący rozgraniczenia obustronnych stref interesów w Europie Wschodniej. Po agresji Niemiec (1 IX 1939 r.) i ZSRR (17 IX 1939 r.) na Polskę, zanim ostatecznie zamknięto granice, ok. 300 tys. Żydów ze strefy niemieckiej okupowanej Polski uciekło przed nazistami do Związku Radzieckiego, często w nadziei wyemigrowania do Palestyny. Większość z nich odmówiła przyjęcia obywatelstwa ZSRR i została wywieziona w głąb kraju lub do obozów pracy. Po ataku Niemiec na Związek Radziecki 22 VI 1941 r. Hitler rozpoczął wprowadzanie w życie planu ludobójstwa Żydów europejskich. Na Wschodzie zginęło ok. 2 mln Żydów. Szanse na przeżycie mieli uciekinierzy oraz deportowani w głąb Związku Radzieckiego, wśród nich Żydzi polscy. Do Polski powróciła ze Związku Radzieckiego największa grupa ocalonych, ok. 200 tys. Żydów polskich. Zob. M.C. Steinlauf, Pamięć nieprzyswojona. Polska pamięć zagtady, przeł. A. Tomaszewska, Warszawa 2001, s. 50. 
lat 80. XX w. ${ }^{6}$ We Francji książka o rządzie Vichy La France de Vichy, napisana przez historyka amerykańskiego Roberta Paxtona, ukazała się 10 lat wcześniej, ale dopiero w 1973 r. Opublikowana w 1978 r. przez Serge’a Klarsferlda Mémorial de la déportation des Juifs de France (Ksiega pamięci Żydów deportowanych z Francji) z nazwiskami wszystkich deportowanych Żydów (było ich 76 tys.) oraz Ksiegga pamięci dzieci (11 tys.) to początek europejskiego dyskursu z historią i pamięcią III Rzeszy.

Muzeum Auschwitz-Birkenau często odwiedzano w Polsce w ramach szkolnych wyjazdów jako miejsce martyrologii narodu polskiego. Pomiędzy 1989 a 2000 r. uczniowie przyjeżdżali rzadziej (niewątpliwa reakcja na częściową depolonizację miejsca pamięci), ale od 2001 r. obserwujemy stały wzrost wizyt ${ }^{7}$. Rozwój tanich lotów, szczególnie po 2005 r., miał także wpływ na masową turystykę, w tym „czarną turystykę" („tanatoturystykę”) do byłych obozów koncentracyjnych i obozów śmierci, w szczególności na frekwencję odwiedzających Muzeum Auschwitz-Birkenau; liczba odwiedzających po 2007 r. przekracza milion osób rocznie i stale rośnie ${ }^{8}$.

Erik H. Cohen' słusznie zauważa, iż temat Szoa jest ściśle związany z antysemityzmem, prawami mniejszości, tożsamością narodową, wartościami uniwersalnymi, relacjami pomiędzy Izraelem a diasporą i ogólnie naturą ludzką. W coraz większym zakresie bywa łączony także z tematyką praw człowieka (w USA i w Europie) i z etyką (głównie w USA). Nadal ograniczany jest potrzebą zapomnienia. Anne Applebaum przytacza słowa Aleksandra Jakowlewa, przewodniczącego rosyjskiej komisji rehabilitacyjnej: Spoteczeństwo jest obojętne na zbrodnie przesztości, ponieważ zbyt wielu ludzi czynnie w nich uczestniczyto ${ }^{10}$, które odnoszą się do zbrodni sowieckich, ale odsłaniają również uniwersalne powody długiego milczenia wobec zbrodni nazizmu.

Postpamięć ${ }^{11}$ Zagłady obejmuje także niechęć do pamięci o indywidualnej kolaboracji w Europie i nowej historiografii odsłaniającej karty ciemnej historii indywidualnej i grupowej współpracy Europejczyków z Niemcami. Postpamięć włącza wszakże, w swoim nieświadomym obszarze, również postawy części Polaków wobec Żydów w okupowanej Polsce. Kategoria postpamięci stworzona przez amerykańską badaczkę z Uniwersytetu Columbia Marianne Hirsch jest pomocna w analizie projektów pamięci o Holokauście, aczkolwiek wymaga każdorazowo analizy zawartości projektów i nie powinna być nadużywana. Postpamięć nie dotyczy własnych doświadczeń, ale tych przeżytych przez poprzednie pokolenia, często traumatycznych. Gdy osoby doświadczone traumą nie wracają do wspomnień, ponieważ przynosi im to ból, wracają do nich

6 W 1983 r. ukazal się numer specjalny katolickiego miesięcznika „Znak” poświęcony tematyce żydowskiej, zatytułowany „Żydzi w Polsce i świecie. Katolicyzm - Judaizm” (1983, nr 2-3).

7 M. Kucia, Auschwitz jako fakt spoteczny. Historia, wspótczesnośc i świadomość spoteczna KL Auschwitz $w$ Polsce, Kraków 2005.

8 Sześć byłych nazistowskich obozów śmierci znajduje się na terytorium obecnej Polski.

$9 \quad$ E.H. Cohen, Identity and Pedagogy. Shoah Education in Israeli State Schools, Boston 2013, s. 56.

10 A. Applebaum, Gutag, przeł. J. Urbański, Warszawa 2013, s. 519.

11 Termin utworzony przez: M. Hirsch, Family Frames. Photography, Narrative and Postmemory, Cambridge 1997. Wcześniej pojawił się w: taż, Family Pictures. Maus, Mourning and Post-Memory, „Discourse" 1992-1993, nr 2, s. 3-29. 
kolejne pokolenia, mimo że niekoniecznie zmniejsza to cierpienie pokrzywdzonych. Powrót pamięcią do traumatycznych wydarzeń może być uzdrawiający, nie jest to jednakże regułą. Ograniczenia dostępu do pamięci mogą być spowodowane nie tylko autocenzurą, ale także celowymi działaniami struktur państwa.

Marianne Hirsch przywołuje termin „miejsca pamięci” (lieux de mémoire) Pierre’a Nory $^{12}$. Miejsca te mogą blokować procesy zapominania. Warto w tym miejscu zaznaczyć, iż Ronit Lentin przestrzega przed powracającym użyciem metaforycznego języka Szoa, który jest częścią wymazywania Zagłady ${ }^{13}$. Przed wymazywaniem pamięci bronią takie inicjatywy w przestrzeni publicznej, jak projekt byłej dyrektorki Żydowskiego Instytutu Historycznego w Warszawie Eleonory Bergman oraz architekta i projektanta Tomasza Leca. Dotyczył on układu punktów zakreślających granice getta warszawskiego w postaci zatopionych w chodniku napisów „Mur getta 1940-1943/Getto Wall 1940-1943" oraz tablic na istniejących fragmentach muru. Rzeźba-instalacja Leca, powstała w oparciu o badania Krzysztofa Pasternaka, upamiętnia kładkę nad ulicą Chłodną, łączącą małe i duże getto ${ }^{14}$. Miejsca pamięci w przestrzeni miasta nie będą jednak funkcjonować w pamięci zbiorowej i świadomości historycznej kolejnych pokoleń bez wysiłku edukacyjnego państwa oraz organizacji pozarządowych.

Głównym pytaniem badawczym leżącym u podstawy tego tekstu jest pytanie o możliwość włączenia (re)konstruowanej postpamięci o Holokauście do kolektywnej pamięci zbiorowej Polaków (poziom kultury narodowej) i do pamięci społeczności lokalnych (poziom regionalny). Ograniczę się do studium przypadku jednej organizacji, a konkretnie: jednego wybranego programu związanego z praktykami społecznymi odnoszącymi się do symboli straty, jaką poniosła kultura polska po Holokauście, oraz rytuałów upamiętnienia życia i śmierci ofiar Holokaustu (wprowadzanymi do przestrzeni publicznej) przez organizację pozarządową Forum Dialogu Między Narodami $(\text { FDMN })^{15}$. Wcześniej przytoczę wybrane refleksje badaczy odnoszące się do zbiorowej pamięci, m.in. propozycję Aleidy Assmann uczynienia z historii Holokaustu wspólnej pamięci dla Europy oraz przykłady ścierania się różnych pamięci Polaków w przestrzeni publicznej w Warszawie.

12 Tamże, s. 22.

13 R. Lentin, Introduction: Postmemory, Unsayability and the Return of the Auschwitz code, [w:] Re-Presenting the Shoah for the Twenty-First Century, red. R. Lentin, New York 2004, s. 15.

14 P. Kosiewski, Zaznaczyć miejsce. Rozmowa z Tomaszem Lecem, Opór i Zagtada. Żydzi w Polsce. Rok 1943, „Tygodnik Powszechny” [dodatek] 2013, nr 16, s. 29.

15 Forum Dialogu między Narodami (http://www.dialog.org.pl/) udziela wsparcia nauczycielom poszukującym strategii w zakresie kontaktów młodzieży polskiej i żydowskiej. Ważną rolę odgrywa także program „Zachować pamięć. Historia i kultura dwóch narodów” realizujący zobowiązania wynikające z umowy między Rządem RP a Rządem Izraela o współpracy kulturalnej, naukowej i oświatowej. Program składający się z komponentu edukacyjnego „Bliżej siebie” dotyczy spotkań młodzieży polsko-izraelskiej. Serwis www.polska-izrael.edu.pl oraz sieć koordynatorów regionalnych programu „Pamięć i edukacja - uczymy się od siebie" przygotowuje nauczycieli do organizacji spotkań młodzieży z Polski i Izraela oraz wspiera ich działania. O projekcie, [online] http://www.polska-izrael.edu.pl/index. php?option=com_k2\&view=item\&layout=item\&id=125\&Itemid=419\&lang=pl, 29 II 2016. Na uwagę zasługuje także publikacja FDMN Trudne pytania w dialogu polsko-żydowskim, Warszawa 2006. 
Aleksandra Ubertowska, przywołując Haralda Weinricha, przypomina o Holokauście (Szoa) ${ }^{16}$ jako próbie wymordowania catego narodu żydowskiego, [który] może jawić sie jako nieporównywalny i bezprzyktadny zamach, wymierzony w kulturowa pamięć ludzkości, jako [...] mord na pamięci - memoricid ${ }^{17}$. Stąd, jak uzasadnia badaczka, status przysługujący pamięci o Zagładzie w tak wielu dziedzinach badań humanistycznych i społecznych.

Termin „pamięć” w naukach społecznych zawdzięcza wiele Maurice'owi Halbwachsowi, który już w latach 20. XX w. zajął się zjawiskiem pamięci zbiorowej, kładąc nacisk na teraźniejszosśc, determinującą to, co i jak pamiętamy z przeszłości. Przywołuję klasyka, aby pokazać, jak różnie może on być interpretowany przez współczesnych historyków (Peter Novick) i literaturoznawców (Aleida Assmann). Aleida Assmann ${ }^{18}$ podkreśla znaczenie traum historycznych, stanowiących istotne punkty odniesienia do przeszłości, w procesach tworzenia tożsamości zbiorowej. Jej zdaniem, Holokaust może stać się paradygmatem i dostarczyć języka, sposobu komunikacji i artykulacji ofiarom innych ludobójstw i traum historycznych. Tymczasem w wielu krajach europejskich pamięci narodowe II wojny światowej pozostają nadal powojennymi, wybiórczymi konstrukcjami z dominującymi, zamrożonymi narracjami narodu-ofiary i/lub narodu-ruchu oporu. Te trwałe paradygmatyczne narracje mają funkcję obronną przed historiografią odsłaniającą kolaborację.

Peter Novick ${ }^{19}$ w swojej polemice z Aleidą Assmann i jej postulatem wspólnej (shared) pamięci Holokaustu dla zjednoczonej Europy traktuje pojęcie „pamięć zbiorowa" jedynie jako metaforę, która może mieć zastosowanie wyłącznie w odniesieniu do społeczeństw przednowoczesnych, tradycyjnych, jednolitych. Metafora ta w stosunku do fragmentarycznych, stale zmieniających się społeczeństw przełomu XX i XXI w. w dobie komunikacji elektronicznej wydaje się Novickowi problematyczna. Historyk

16 Dan Michman, emerytowany główny historyk Yad Vashem, w wykładzie wygłoszonym 29 VI 2014 r. w Jerozolimie dla doktorantów Saul Kagan Fellowship uporządkował określenia używane zamiennie na określenie Zagłady Żydów. Termin „Szoa” jest znany od lat 30. XX w., termin „ludobójstwo” pojawił się natomiast w 1943 r., a w publikacjach zaistniał w 1944 r. jako idea, w kontekście zapobiegania zbrodniom wobec narodów lub innych grup ludzi. Do lat 70. był używany w związku z Holokaustem. Wybitny historyk izraelski Yehuda Bauer uważa Holokaust za ekstremalną formę ludobójstwa. Natomiast Michman, przypominając, że w biurze Eichmanna znajdowały się listy Żydów z całego świata, nie zrównuje Holokaustu z ludobójstwem. Zamiarem inżynierów Holokaustu było według niego oczyszczenie narodu niemieckiego i świata z nośników żydowskiego ducha, zniszczenie Jewish mind.

17 H. Weinrich, Lethe. Kunst und Kritik des Vergessens, München 2000, s. 232, [cyt. za:] A. Ubertowska, Literatura i pamięć o Zagtadzie: Archiwa, ślady, krypty, [w:] Stosowność i forma. Jak opowiadać o Zagtadzie?, red. M. Głowiński i in., Kraków 2006, s. 265.

18 A. Assmann, Europe: A Community of Memory? (20 th Annual Lecture, November 16, 2006), „GHI Bulletin” 2007, nr 40, [online] https://www.ghi-dc.org/fileadmin/user_upload/GHI_Washington/ Publications/Bulletin40/011.pdf, 25 II 2016; taż, Response to Peter Novick, „GHI Bulletin” 2007, nr 40, [online] https://www.ghi-dc.org/fileadmin/user_upload/GHI_Washington/Publications/ Bulletin40/033.pdf, 25 II 2016.

19 P. Novick, Comments on Aleida Assmann's Lecture, „GHI Bulletin” 2007, nr 40, s. 27-31, [online] https://www.ghi-dc.org/fileadmin/user_upload/GHI_Washington/Publications/Bulletin40/027. pdf, 25 II 2016. 
nie podziela zatem opinii Assmann, że Zagłada może pełnić rolę „założycielskiego mitu" zjednoczonej Europy. Jest zdania, iż inne państwa - poza Niemcami - nie przyjmą zaproszenia do partnerstwa w odpowiedzialności za Holokaust. Podając przykład Stanów Zjednoczonych, stwierdza, że wspólna świadomość historyczna nie jest warunkiem koniecznym wspólnoty politycznej. Novick odnosi się także krytycznie do instrumentalizacji stosowanej przez pamięci zbiorowe, a mianowicie dowolnego doboru faktów historycznych do upamiętniania, w zależności od aktualnych potrzeb politycznych, gdyż zawsze z definicji służą one celom teraźniejszości, a zatem instrumentalizacja jest pustą kategorią, o nikłej analitycznej przydatności.

W odpowiedzi Assmann podkreśla konstruktywistyczne podejście do terminu „pamięć zbiorowa”, uwzględniające wpływ symboli kulturowych na postrzeganie przeszłości, rozwijające się wraz z rozwojem badań nad pamięcią i tożsamością zbiorową od lat 80. A zatem, broni swojego punktu widzenia, termin „pamięć zbiorowa” nadaje się do analiz społeczeństw końca XX w. Tłumaczy także, w tym samym Biuletynie Niemieckiego Instytutu Historycznego w Waszyngtonie, iż jest daleka od postaw rewizjonistycznych pomniejszających winę i odpowiedzialność Niemców. Zauważa, że tam, gdzie jest ofiara, jest także oprawca i nie są to stałe kategorie przypisane niezmiennie tym samym ludziom. Wspólna pamięć nie oznacza jednej pamięci czy tych samych podręczników, ale podzielaną/wspólną „świadomość historyczną” wydarzeń i ich ciągów przyczynowych. Assmann zgadza się z Novickiem, iż społeczeństwo nie jest żywym organizmem ze zbiorowym umysłem i wspólnym imaginarium oraz podkreśla, że pamięć jest różnie konstruowana na różnych poziomach: jednostki, rodziny, społeczeństwa i narodu. Pamięci zbiorowe powinny jednak opierać się na podbudowie konstruowanej na wspólnej wiedzy i wartościach, a same z kolei stanowić bazę dla świadomości historycznej. W polemice z Novickiem Assmann nie postuluje ujednolicenia pamięci narodowych, ale uważa, iż w ich negocjowaniu konieczny jest wspólny punkt odniesienia, aby zmniejszyć różnice i uczynić pamięci narodowe bardziej zgodnymi ze sobą.

Zastanawiając się nad propozycją Assmann „wspólnej pamięci” dla Europy, warto przypomnieć fakty historyczne: 350 tys. Żydów zamordowanych przez Rumunów na Ukrainie, 600 tys. Żydów deportowanych do obozów przez rząd Węgier pod koniec II wojny światowej, likwidację getta w Kownie przez Litwinów, udział obywateli krajów bałtyckich w formacjach mordujących Żydów. Podobną gorliwością odznaczały się: Słowacja, Francja Vichy, Chorwacja, Serbia. Nawet Bułgaria, broniąc „swoich”, wydała „nieswoich” Żydów z Macedonii i Tracji. Należy pamiętać nie tylko o szmalcownikach, lecz także o mordowaniu Żydów ukrywających się na terenie okupowanej Polski przez niektórych Polaków i grupy partyzantów, również z Armii Krajowej.

Dla obrazu historii pamięci i świadomości Zagłady w Polsce ważna jest konfrontacja danych uzyskanych z różnych źródeł, na różnych poziomach: oficjalnych deklaracji i zobowiązań państwa, publikacji programów szkolnych i podręczników uwzględniających stan wiedzy i postawy młodzieży wobec Holokaustu, a także prezentacji konkretnych działań jednostek w lokalnych społecznościach. W przestrzeni aktywności organizacji międzyrządowych ogólnoświatowe upowszechnienie pamięci o Holokauście jest działaniem zaledwie ostatnich 20 lat i zawdzięczamy je niewątpliwie Forum 
$46^{20}$ - forum rządów, które podpisały Deklarację Sztokholmską, zwołanym z inicjatywy premiera Szwecji Görana Perssona w dniach 26-28 stycznia 2000 r. Bezpośrednią przyczyną był niepokój premiera związany z badaniami młodzieży szwedzkiej w $1997 \mathrm{r}$. (próba 7927 osób w wieku 12-18 lat), które wykazały, że 30\% badanych młodych Szwedów nie wierzy, iż Holokaust kiedykolwiek miał miejsce. Jest to przykład bezpośredniego wpływu badań opinii publicznej na decyzje polityczne, które przyniosły pozytywne dla woli upamiętnienia Holokaustu efekty w całym świecie. Zagadnienie, czy wola ta była traktowana przez niektóre państwa wyłącznie jako przepustka do społeczności UE, wymagałoby oddzielnych badań. Punkt 4. Deklaracji dotyczący woli politycznej brzmi: Zobowiązujemy się zwiększyć nasze wysitki mające na celu promowanie edukacji, upamiętnienia i badań nad Holokaustem zarówno w krajach, które podjęty już dziatania $w$ tej dziedzinie, jak też w krajach, które chca przytączyć się do naszych wysitków. Polska jest państwem-sygnatariuszem Deklaracji Sztokholmskiej. Rezolucja PE 354.156 Parlamentu Europejskiego w sprawie pamięci o Holokauście, antysemityzmu i rasizmu została podjęta w 2005 r. ze skutkiem ustanowienia 27 stycznia Europejskim Dniem Pamięci o Holokauście w całej UE. Zobowiązania rządów państw-sygnatariuszy do promowania edukacji o Holokauście dotyczą wspierania badań, pamięci i edukacji o Zagładzie, ale nie uwzględniają jakości promowanych działań i dzieł ${ }^{21}$. Aby zorientować się, jakie strategie przyczyniają się do zwiększenia wiedzy i świadomości historycznej, a jakie nie są w ogóle skuteczne, konieczne były longitudinalne badania porównawcze. Trwające trzy lata badania International Holocaust Remembrance Alliance, organizacji, która powstała w 1998 r. i doprowadziła do podpisania Deklaracji Sztokholmskiej, zostaną wkrótce opublikowane ${ }^{22}$.

20 Wcześniej, w 1998 r., powstała organizacja International Task Force for Holocaust Remembrance, Education and Research (ITF), obecnie nosząca nazwę International Holocaust Remembrance Alliance (IHRA). Polska jest członkiem IHRA.

$21 \mathrm{Na}$ uwagę zasługują polskie i zagraniczne prace z wieloma refleksjami i rekomendacjami w zakresie edukacji o Zagładzie oraz dorobek Centrum Badań nad Zagładą w PAN w Warszawie związany z przygotowaniem materiałów do nauczania o Zagładzie dla polskich edukatorów. Zob. T. Kranz, Pedagogika pamięci jako forma edukacji muzealnej, [w:] Wizyty edukacyjne w Państwowym Muzeum na Majdanku. Poradnik dla nauczycieli, red. tenże, Lublin 2012, s. 11; P. Trojański, Edukacja o Holokauście w Polsce. Próba krytycznego bilansu, [w:] Edukacja muzealna w Polsce. Aspekty, konteksty, ujęcia, red. W. Wysok, A. Stępnik, Lublin 2013; M. Kucia, Optymistyczne dane - niepokojace pytania - radykalne wnioski, [w:] Auschwitz i Holokaust. Dylematy i wyzwania polskiej edukacji, red. P. Trojański, Oświęcim 2008, s. 35-44; Wybór źródet do nauczania o Zagtadzie Żydów na okupowanych ziemiach polskich, wybór i oprac. zespół pod kierunkiem A. Skibińskiej i R. Szuchty, wstęp i słownik terminów R. Szuchta, wybór oprac. i wstęp do rozdz. Świadectwa literackie W. Młynarczyk, Warszawa 2010; B. Jędruszczak, W. Młynarczyk, R. Szuchta, Wybór źródet do nauczania o zagtadzie Żydów na okupowanych ziemiach polskich. Cwiczenia, Warszawa 2010; Holocaust Education in a Global Context, red. K. Fracapane, M. Haß, współpr. Topography of Terror Foundation, Berlin-Paris 2014; M. Gross, To Teach the Holocaust in Poland: Understanding Teachers' Motivations to Engage the Painful Past, „Intercultural Education" 2013, Vol. 24, nr 1-2, s. 103-120, [online] http://doi.org/10.1080/14675986.2013. 773126, 25 II 2016.

22 International Holocaust Remembrance Alliance, Research in Teaching and Learning about the Holocaust. A Dialogue Beyond Borders, red. M. Eckmann, D. Stevick, J. Ambrosewicz-Jacobs, Berlin 2017, IHRA Series, 3. 
Poświęciłam uwagę wybranej debacie współczesnych intelektualistów nad pojęciem „pamięci”, gdyż wydaje mi się, że w ostatnim dwudziestoleciu w Polsce i w Europie mamy do czynienia z dwiema niekiedy sprzecznymi tendencjami, które zostały odzwierciedlone w badaniach opinii publicznej i działaniach w przestrzeni publicznej. Niektóre sondaże pokazują zmęczenie historią, w szczególności historią II wojny światowej, w tym Holokaustu, a jednocześnie mamy do czynienia wręcz z „nadmiarem pamięci” w niektórych sferach życia publicznego i sztuki. W odniesieniu do Polski Andrzej Szpociński pytał: [...] oto bowiem z jednej strony mamy do czynienia z niezwykle rozbudowanym dyskursem o przesztości narodowej w sferze publicznej, zdrugiej zaś - odnotowanym $w$ badaniach spadkiem zainteresowania spoteczeństwa polskiego przesztościa. narodowa. Jak wyjaśnić te sprzeczność? ${ }^{23}$

Wybitna polska badaczka pamięci zbiorowej Barbara Szacka ujawniła, że w badaniach przeprowadzonych w Polsce w 1988 r. wśród ludzi z wyższym wykształceniem 69\% respondentów uważało, że znajomość przesztości historycznej jest potrzebna wspótczesnemu cztowiekowi, podczas gdy w badaniach z 2003 r. tylko 49\% badanych podzielało to zda$n_{i e}{ }^{24}$. Pomimo zmniejszającego się z czasem zainteresowania historią, wydarzenia i zachowania związane z czasami II wojny światowej pozostają w Polsce powodem do dumy, a bardzo rzadko powodem wstydu. Na przestrzeni lat II wojna światowa niezmiennie była powodem do dumy - jak wskazują badania ilościowe, według 36\% badanych w latach 1965 i 1977 oraz 45\% w 1988 r. ${ }^{25}$ Badania postaw Polaków Ireneusza Krzemińskiego z 2002 r. ujawniły, że 55\% respondentów było przekonanych, iż Polacy nie mogli uratować więcej Żydów, a 26\% badanych było przeciwnego zdania. $72 \%$ respondentów uważało, że Polacy nie mają powodów do wyrzutów sumienia z powodu postaw wobec Żydów w czasie wojny, a tylko $12 \%$ uważało, że mają. W badaniach Pentora z 2003 r. tylko 3\% badanych wstydziło się za negatywny stosunek do Żydów w czasie wojny ${ }^{26}$. W badaniach jakościowych pojawiało się Jedwabne: Dziadek zapytany, czy wierzy w Jedwabne, to powiedziat, że Jedwabne to wierzchotek góry lodowej ${ }^{27}$. Do przypadków mordowania Żydów przez Polaków, opisanych i badanych przez polskich i zagranicznych historyków, dochodziło oprócz Jedwabnego również w wielu innych miejscowościach, np. w Radziłowie, Szczuczynie, Stawiskach. Należą one do „niewypowiadanych opowieści”28.

Wyniki badań instytutu IMAS w Linzu i Harris Interactive z 2005 r. ${ }^{29}$ przeprowadzone wśród 20 tys. respondentów w 13 krajach w 60. rocznicę zakończenia II wojny

23 A. Szpociński, Pamięć przesztości i strategie legitymizacyjne, [w:] Pamięć. Rejestry i terytoria. Memory. Registers and Territories, red. P. Orłowska, przeł. J. Taylor-Kucia, Kraków 2013, s. 27.

24 B. Szacka, Czas przeszty, pamięć, mit, Warszawa 2006, s. 52, Wspótczesne Spoteczeństwo Polskie Wobec Przesztości, 3.

25 Tamże, s. 159-161.

26 Pentor, Duma i wstyd. Wielkie badanie pamięci zbiorowej, „Gazeta Wyborcza” 2004, 17 IX.

27 B. Szacka, Czas przeszty..., s. 165.

28 Określenie zaczerpnęłam z pracy: K. Kaźmierska, Biografia i pamięć. Na przyktadzie pokoleniowego doświadczenia ocalonych z Zagłady, Kraków 2008, s. 117.

29 Harris Interactive and IMAS International Conduct Thirteen-Country Survey in Remembrance of 60th Anniversary of World War II, [online] http://www.prnewswire.com/news-releases/harris-interactive- 
światowej wskazują, że duży odsetek społeczeństw oczekuje zapomnienia o wojnie. Jednocześnie istnieje przeciwstawna tendencja - do pamięci o II wojnie światowej, poszukiwania historii rodzinnych wśród młodego pokolenia czy śladów pamięci Zagłady w świadectwach ofiar i świadków. Postpamięć II wojny światowej i postpamięć Holokaustu nieustannie ścierają się ze sobą, tocząc niejednokrotnie bój o przestrzeń publiczną, z niesymetrycznie rozłożonymi siłami w niektórych krajach.

W dyskursie dotyczącym Zagłady obok postpamięci pojawiają się także inne terminy: przeciw-pamięć (counter-memory), pamięć alternatywna, konkurencyjna lub opozycyjna. Michel Foucault ${ }^{30}$ uważa, iż przeciw-pamięć dotyczy pamięci jednostek i grup wykluczonych, pozostających poza oficjalną narracją państwową dyktowaną przez posiadające władzę elity polityczne. Jest to pamięć spontaniczna, oddolna, przeciwstawiająca się opresyjnej pamięci rządzących, najczęściej analizowana w kontekście konfliktów etnicznych czy historii krajów postkolonialnych. Wydaje się, że ten termin może być także zastosowany w przypadku pamięci Zagłady w Europie Środkowo-Wschodniej, o którą w czasach zimnej wojny nie miał się kto tutaj upomnieć. To pamięć inicjowana przez liderów organizacji pozarządowych lub z potrzeby serca lokalnych nauczycieli. Wraz ze zmianą ustroju politycznego przeciw-pamięć istniejąca $\mathrm{w}$ drugim, nieoficjalnym obiegu i w pamięci rodzinnej może stać się pamięcią oficjalną i tłumić inne obszary pamięci. W Polsce przez lata pamięcią pomijaną, zniekształcaną i wykluczoną była właśnie pamięć o Zagładzie.

Tzvetan Todorov w Les Abus de la Mémoire ${ }^{31}$ zwrócił uwagę, że reżimy totalitarne kontrolują informację w procesie systematycznej destrukcji pamięci. Przykładem niespotykanej wręcz próby kontroli był plan Himmlera z 1942 r. mający na celu zatarcie śladów zbrodni III Rzeszy w Europie Wschodniej, zwłaszcza zbiorowych morderstw na Żydach popełnianych przez Einsatzgruppen, noszący nazwę „Akcja 1005”. Nazwa operacji, o której pisze w swojej książce The Holocaust by Bullets francuski ksiądz Patrick Desbois $^{32}$, zaangażowany w odkrywanie zbiorowych grobów zamordowanych na terenach Ukrainy Żydów, pochodzi od numeru klasyfikacji listów. Trwająca od lata 1942 do końca 1944 r. Akcja 1005 polegała na wykopywaniu ofiar III Rzeszy i paleniu ich ciał na wielkich paleniskach, na których mogło się ich pomieścić nawet 2 tys. Za operację usuwania ciał świadczących o rozmiarach zbrodni odpowiedzialny był Paul Blobel, ten sam, który odpowiadał za zbrodnie popełnione w Babim Jarze. Zdefiniowany przez system totalitarny III Rzeszy naród żydowski został skazany na śmierć, a ślady zbrodni starano się zatrzeć, aby nie pozostawić na to żadnych dowodów, a zatem zniszczyć pamięć o nich. Paradoksalnie, jej nośnikiem stały się zmysły i pamięć jednostek i grup społecznych, mieszkańców pobliskich wiosek, którzy nie mogli zapomnieć strasznego zapachu palonych ciał. Konfiskata pamięci nie odnosi się jednakże wyłącznie do

and-imas-international-conduct-thirteen-country-survey-in-remembrance-of-60th-anniversary-of-world-war-ii-54587947.html, 20 II 2016.

30 M. Foucault, Language, Counter-Memory, Practice. Selected Essays and Interviews, przeł. D.F. Bouchard, S. Simon, Ithaca 1977.

31 T. Todorov, Les Abus de la Mémoire, Paris 1995.

32 P. Desbois, The Holocaust by Bullets. A Priest's Journey to Uncover the Truth Behind the Murder of 1.5 Million Jews, New York 2008, s. 153. 
systemów totalitarnych, ale może stać się strategią wszystkich zapatrzonych w chwalebną przeszłość, odwracających się od przykładów hańby, szukających w przeszłości pociechy lub/i kompensacji aktualnych niepowodzeń lub po prostu braku sukcesów.

Przykładem działania w przestrzeni publicznej postpamięci w Austrii jest projekt artystyczny Christophera Mayera „Audiowalk Gusen” („Audiospacer Gusen”) ${ }^{33}$, angażujący od 2007 r. publiczność w konfrontację z przeszłością poprzez głosy byłych więźniów obozu koncentracyjnego Gusen I i II, świadków oraz oprawców. W obozie Gusen zginęło 37 tys. ze 120 tys. ofiar obecnego terytorium Austrii. To, o czym słyszą uczestnicy spaceru w słuchawkach, nie jest widoczne, tylko wyobrażone, gdyż spacer odbywa się w willowej dzielnicy mieszkalnej. Krajobraz nie uwidacznia śladów przeszłości, o której chciano po wojnie zapomnieć, a haniebna i bolesna przeszłość może zostać jedynie odtworzona w oparciu o świadectwa świadków epoki.

Barbara Szacka w książce Czas przeszty, pamięć, mit ${ }^{34}$ przytacza sposoby przekształcania pamięci wyodrębnione przez Roya F. Baumeistera i Stephena Hastingsa (1997). Uczeni amerykańscy wyróżnili: 1. pomijanie (selektywne przemilczanie nieprzyjemnych faktów), 2. fałszowanie (wraz z towarzyszącym mu zaprzeczaniem lub dodawaniem faktów), 3. wyolbrzymianie i upiększanie, 4. manipulowanie związkami pomiędzy faktami, czyli stronniczą interpretację, 5. obwinianie nieprzyjaciół (dla minimalizowania własnych win i projektowania własnych win na wrogów), 6. zrzucanie winy na okoliczności oraz 7. konstruowanie kontekstu (upraszczanie dla wzmocnienia pozytywnego wizerunku własnej grupy).

Odsłonięty w 1948 r. pomnik Bohaterów Getta w Warszawie honorował powstańców getta, a jako jedyny w stolicy pomnik II wojny światowej oprócz pomnika Armii Czerwonej „unieważniał” powstanie warszawskie i walkę $\mathrm{AK}^{35}$. W dotychczasowych grupowych reprezentacjach relacji polsko-żydowskich, szczególnie w czasie debat wywołanych istotnymi tekstami (Jan Błoński ${ }^{36}$, Jan Tomasz Gross ${ }^{37}$ ), odnajdujemy wszystkie powyższe typy przekształcania pamięci. Ich celem jest głównie podtrzymanie wizerunku bohaterskich i szlachetnych Polaków. To reakcja na publikacje nowej historiografii czy eseje apelujące do etyki zbiorowej, które burzą ten wizerunek. Skupianie się na pozytywnym autowizerunku, szczególnie w momentach mu zagrażających, blokuje przyswajanie pomijanych dotąd faktów historycznych, takich jak przypadki (indywidualnej) kolaboracji Polaków z okupantem lub tropienie ukrywających się w czasie Zagłady Żydów, a także wrażliwość na cierpienia grupy innej niż własna.

Narodowo-martyrologiczny kanon procesu socjalizacji [...] przestaniat nam (i ciagle przestania) cierpienia innych narodów - pisał Robert Traba ${ }^{38}$. W przestrzeni publicznej

33 Audiowalk Gusen, [online] http://audioweg.gusen.org/en/, 20 II 2016.

34 B. Szacka, Czas przeszty..., s. 29-30.

35 K. Kaźmierska, Biografia i pamięć..., s. 131.

36 J. Błoński, Biedni Polacy patrza na getto, „Tygodnik Powszechny” 1987, nr 2, s. 1.

37 J.T. Gross, Sasiedzi. Historia zagtady żydowskiego miasteczka, Sejny 2000; tenże, Strach. Antysemityzm w Polsce tuż po wojnie. Historia moralnej zapaści, Kraków 2008; J.T. Gross, I. Grudzińska-Gross, Ztote żniwa. Rzecz o tym, co się dziato na obrzeżach zagtady Żydów, Kraków 2011. 
czasami wręcz zasłaniał upamiętnienie cierpienia Innych. W eseju Pamięć i tożsamość w przestrzeni dawnego getta warszawskiego, opublikowanym w ważnym numerze kwartalnika „Herito” poświęconym konfliktom pamięci, Elżbieta Janicka ${ }^{39}$ pisze o strategiach neutralizacji wobec pamięci Zagłady w Warszawie odzwierciedlonych w procedurach pacyfikacyjnych, wśród których wyróżnia najczęściej stosowane obstawienie. Jako przykład wymienia skromny pomnik z 1988 r. usytuowany wzdłuż ulicy Stawki, upamiętniający deportację ponad 300 tys. obywateli polskich - warszawskich Żydów z dawnego Umschlagplatz i umieszczony na środku ulicy, na skwerze Matki Sybiraczki, pomnik Poległym i Pomordowanym na Wschodzie z 1995 r. w formie wagonu z krzyżami, zwany potocznie Golgotą Wschodu. Pomnik upamiętniający ok. 320 tys. obywateli polskich różnych narodowości (w tym 70 tys. pochodzenia żydowskiego) deportowanych na wschód, w przeciwieństwie do pomnika upamiętniającego Żydów warszawskich, nie ma nic wspólnego z lokalizacją na terenie dawnego placu Muranowskiego, który stanowił jeden z ważniejszych punktów żydowskiego oporu podczas powstania w getcie. Historia miejsca, jak pisze Janicka, jest „uwidoczniona” w sposób niezbyt wyraźny (pleksiglas przysłonięty drzewami) i bez informacji o donosach na żołnierzy Żydowskiego Związku Bojowego, po ich wyjściu z getta na aryjską stronę, w wyniku których zginęli.

O przestrzeni byłego getta warszawskiego piszą cytowani już wcześniej autorzy monografii historycznej getta Engelking i Leociak: Miejsce-po-getcie jest puste (chociaż zabudowane), jest ogotocone $i$ martwe (chociaż wre tam życie). Miejsce ocalato, ale zostato niejako wydrązone, pozbawione „treści”, „wnętrza”. Getto, które tutaj byto, ulegto zagtadzie, ale owo "tutaj” pozostato, zastonięte jednak obecnościa dzisiejszego Muranowa. Zostaty ramy, które mieszcza w sobie już inna rzeczywistość, pozostat punkt topograficzny, kartograficzna abstrakcja ${ }^{40}$. Ta inna rzeczywistość stolicy Polski jest dodatkowo przysłaniana, jak ukazuje Janicka, reprezentacją przeszłości związanej z historią stalinizmu, którego ofiarami byli Polacy o różnych korzeniach etnokulturowych i religijnych.

Przed zasłonięciem i zapomnieniem mogą ocalić projekty edukacyjne związane z przestrzenią Warszawy i innych miast oraz mniejszych miejscowości w Polsce, realizowane przez samorządy i organizacje pozarządowe. Przykładem jest działalność FDMN, która w 2010 r. objęła ponad 550 uczniów szkół gimnazjalnych i ponadgimnazjalnych z Warszawy oraz małych miejscowości o bogatej historii żydowskiej. O dynamice rozwoju działań FDMN świadczy fakt, że w 2015 r. w warsztatach edukacyjnych Szkoły Dialogu wzięło udział ponad 40 szkół w całej Polsce. W ramach wizyt studyjnych organizację odwiedziło 85 gości ze Stanów Zjednoczonych, Australii, Kanady, Wielkiej Brytanii i Izraela, którzy aktywnie uczestniczyli w polsko-żydowskim dialogu ${ }^{41}$. Szerzej działania FDMN zostaną omówione na przykładzie studium przypadku w dalszej części tekstu.

39 E. Janicka, Pamięć i tożsamość w przestrzeni dawnego getta warszawskiego, „Herito” 2013, nr 13, s. 66-81.

41 Newsletter Forum Dialogu Między Narodami, 2 II 2016, [online] http://www.dialog.org.pl/news_ gala_szkoly_dialogu_2010.html, 11 II 2016. 
Heroiczno-martyrologiczny autowizerunek, jak słusznie dowodzi Janicka, dotyczy nie tylko Polaków. Jest obecny w wielu krajach Europy Środkowo-Wschodniej i uzyskał legitymizację także na poziomie decyzji politycznych UE, gdy Parlament Europejski ustanowił Dzień Pamięci Ofiar Reżimów Totalitarnych, przyczyniając się do umocnienia dyskursu „dwóch ludobójstw” i zrównania ofiar obu systemów totalitarnych.

W Polsce nie zostały, niestety, przeprowadzone badania podobne do tych zespołu Haralda Welzera, które ujawniły rozbieżności pamięci rodzinnej Niemców (wspomnienia przechowywane w „rodzinnych albumach”, zgodnie z metaforą badaczy) i pamięci oficjalnej (metafora naukowego „leksykonu” opartego na faktach historycznych). Dysonans poznawczy zostaje zniwelowany w oparciu o strategię wyłączenia opowieści rodzinnych z kontekstu historycznego. Dyskurs prywatny, jak wykazały badania niemieckie, nie jest tożsamy z dyskursem publicznym.

W Polsce mieliśmy do czynienia z nikłym oddźwiękiem publicznym na publikacje Zespołu Centrum Badań nad Zagładą w Warszawie: kierującej Centrum Barbary Engelking, Jana Grabowskiego, Jacka Leociaka, Małgorzaty Melchior, Dariusza Libionki, Andrzeja Żbikowskiego, Agnieszki Haskiej, Marty Janczewskiej, Aliny Skibińskiej i Jakuba Petelewicza ${ }^{42}$ czy na publikacje Marcina Zaremby, Joanny Tokarskiej-Bakir i wielu innych przedstawicieli historii krytycznej w Polsce. Zygmunt Bauman stwierdził podczas konferencji upamiętniającej w 2007 r. 60-lecie powstania Państwowego Muzeum Auschwitz-Birkenau, że egzorcystów przybywa, ale przybywa także ciemnych zakamarków w historii i pamięci Zagłady. Bardzo trudno porzucić heroiczno-martyrologiczną i zmitologizowaną wersję narodowych historii w Europie Środkowo-Wschodniej, dotkniętej traumą dwóch systemów totalitarnych. Status narodu-ofiary z definicji wyklucza zachowania haniebne, nieprzyzwoite, trudne do zaakceptowania, „zamiatane pod dywan", przysłaniane w przestrzeni publicznej przez pomniki poświęcone własnemu cierpieniu. Strategia ta znana jest m.in. z przypadku Austrii, która bardzo długo odmawiała przyjęcia odpowiedzialności za zbrodnie narodowego socjalizmu. W ostatnim dziesięcioleciu rozkwitają w tym kraju projekty badawcze i artystyczne organizacji pozarządowych i zwykłych obywateli, odnoszące się do obywatelskiej odpowiedzialności za los Żydów w czasie Holokaustu.

Również w Polsce trwa proces zwracania się ku przeszłości, szczególnie nasilony po 2000 r., obejmujący lokalną historię Żydów polskich. W 2001 r. Towarzystwo Inicjatyw Twórczych „ę”, przy wsparciu Fundacji Forda i Akademii Rozwoju Filantropii w Polsce, zrealizowało projekt „Ballada o Szydłowcu”, włączający historię kultury żydowskiej w historię i czasy współczesne Szydłowca. Punktem wyjścia było zdjęcie polsko-żydowskiej klasy miejscowego gimnazjum, a uczniowie odkrywali ślady kultury żydowskiej w swoim własnym mieście.

Uczniowie polscy i żydowscy w ramach programu „Antyschematy” (działającego w latach 2000-2009), utworzonego przez Jerzego Fornalika, nauczyciela Ośrodka Szkolno-Wychowawczego w Borzęciczkach w Wielkopolsce, porządkowali zaniedbane cmentarze żydowskie, m.in. w Andrychowie, Koźminie Wielkopolskim, Krzepicach,

42 Na szczególną uwagę zasługuje kilkanaście tomów rocznika „Zagłada Żydów. Studia i Materiały”. 
Dobrodzieniu, Radomsku, Białej koło Prudnika, Kamiennej Górze, Żabnie, Zduńskiej Woli, Płaszowie, Kłodzku, Lesku, ukraińskich Brodach. Sprzątaniu cmentarzy towarzyszyły warsztaty integracyjne, służące m.in. przełamywaniu uprzedzeń między młodzieżą polską a żydowską. Powstała w 2008 r. organizacja Antyschematy 2, przekształcona w fundację w 2014 r., działa przede wszystkim na terenie województw małopolskiego i podkarpackiego. Jej prezesem jest Tomasz Malec, zaangażowany m.in. w warsztaty z ornamentyki namacewnej, które odbywały się w latach 2008-2014 w Rymanowie, Jaśle, Ołpinach i Nowym Żmigrodzie, warsztaty dotyczące wielokulturowości Tarnowa oraz Międzywojewódzkie Konkursy Korczakowskie dla młodzieży ze szkół specjalnych $\mathrm{i}$ integracyjnych.

Olkuskie Stowarzyszenie Kulturalne „Brama” opracowało treść tablic poświęconych pamięci olkuskich Żydów i przy wsparciu finansowym olkuskiego magistratu zawiesiło je na murze lokalnego Muzeum Pożarniczego. Żydzi stanowili jedną trzecią mieszkańców tego miasta. W trakcie likwidacji getta w Olkuszu w ciągu dwóch dni wywieziono i zgładzono 3,5 tys. Żydów. Członkowie stowarzyszenia „Brama” sami ustawiali macewy na uprzednio zarośniętych cmentarzach żydowskich. $Z$ czasem w porządkowaniu dwóch cmentarzy żydowskich zaczęli brać udział także bezrobotni, których w ramach programu „Konserwator” zatrudniło Przedsiębiorstwo Gospodarki Komunalnej w Olkuszu.

W prowadzonych przeze mnie badaniach nad pamięcią o Zagładzie w Polsce obserwowałam, jak oddolne inicjatywy liderów są przyjmowane przez lokalną społeczność ${ }^{43}$. O projektach „Bramy Grodzkiej-Teatru NN”, pracy Roberta Szuchty z młodzieżą w Treblince i Tykocinie, Towarzystwie Dawida Rubinowicza w Bodzentynie pisałam $\mathrm{w}$ innych pracach ${ }^{44}$. Zasadniczym pytaniem skierowanym do działań FDMN jest: czy organizacja w swoich działaniach przywracania pamięci o polskich Żydach wśród młodych Polaków zapobiega - jak pisał Robert Traba o obowiązkach pamięci w książce o wymownym tytule Historia - przestrzeń dialogu - [...] strategiom zapominania, które sa ślepe, niczego nie wiedza i stuża unikaniu odpowiedzialności $i^{45}$ ?

Analizę działań FDMN przedstawiono m.in. w oparciu o informacje Jakuba Petelewicza z FDMN i raport z obserwacji uczestniczącej warsztatu trenerek FDMN

43 Za udział w badaniach oraz raporty dziękuję Szymonowi Beźnicowi oraz zespołowi ekspertów i doktorantów współpracujących z Centrum Badań Holokaustu UJ, w szczególności: dr Joannie Stöcker-Sobelman, dr Dagmarze Mrozowskiej, Katarzynie Kopff-Muszyńskiej, Elisabeth Büttner, Katarzynie Suszkiewicz, Agnieszce Zajączkowskiej-Drożdż, Katarzynie du Vall, Robertowi Szuchcie. Tragicznie zmarła w katastrofie pod Szczekocinami Maja Brand była zaangażowana w wiele projektów od momentu otwarcia Centrum Badań Holokaustu UJ. Pamiętamy o tym z wdzięcznością.

44 Zob. m.in.: J. Ambrosewicz-Jacobs, Postpamięć Zagtady w Polsce. Dobre praktyki w edukacji nieformalnej, [w:] Miejsce po - miejsce bez. Konferencja zorganizowana przez Muzeum Historyczne Miasta Krakowa, 9-11 kwietnia 2015 roku w ramach wydarzenia Pamiętaj z nami, Kraków 2015, s. 325-338; taż, Meandry pamięci i niepamięci Holokaustu. Koniecznośc ewaluacji praktyk edukacyjnych w oparciu o badania empiryczne, [w:] Nasza szafa. Kultura, edukacja, animacja. Czerwiec-listopad 2014, red. A. Dąbrowicz, B. Muras, Łódź 2014, s. 38-49; J. Ambrosewicz-Jacobs, E. Büttner, Isolated Islands? Memory of the Holocaust in Formal and Informal Education. The Case Study of Post-Communist Poland, „Politeja” 2014, Vol. 11, nr 27, s. 81-106, [online] http://dx.doi.org/10.12797/politeja.11.2014.27.04.

R. Traba, Historia - przestrzeń dialogu..., s. 35 . 
przeprowadzonej przez Szymona Beźnica 10 listopada 2010 r. w Warszawie ${ }^{46}$ w ramach

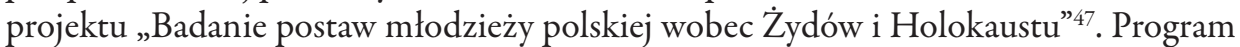
edukacyjny „Szkoła Dialogu”48 skierowany jest do uczniów szkół gimnazjalnych i ponadgimnazjalnych i występuje w dwóch wariantach: „Szkoła Dialogu - Warszawa” jest realizowana w placówkach w Warszawie od 2008 r., a „Szkoła Dialogu - Polska” jest skierowana do młodych ludzi z małych miejscowości o bogatej historii żydowskiej. Celem programu jest poszerzanie wiedzy mtodzieży na temat wielowiekowej obecności Żydów w Polsce poprzez samodzielne odkrywanie i upamiętnianie historii przedwojennej spoteczności żydowskiej w miejscu, w którym żyją9.

Kategoria „dialogu”, obecna zarówno w nazwie stowarzyszenia, jak i w nazwie programu edukacyjnego, przywołuje refleksję izraelskiego filozofa Avishai Margalita, który uważa, że: Pamięć dzielona [ang. shared memory] nie rodzi się więc samoczynnie, w sposób naturalny, lecz jest wynikiem skonstruowanego dialogu, toczaccego się na przyktad między grupami, które odmiennie postrzegaja przesztość i które ksztattuja ja w odmienne narracje ${ }^{50}$. Narracje dotyczące Zagłady w okupowanej Polsce, od czasu zakończenia II wojny światowej, są odmiennie przeżywane i wyrażane przez kolejne pokolenia Żydów i Polaków.

Program FDMN poprzez pracę u podstaw obejmuje przede wszystkim wypełnienie pamięcią przez pokolenie młodych Polaków pustki i straty odczuwanej przez drugie i trzecie pokolenie Żydów odwiedzających Polskę, a nieodczuwanej - z wyjątkiem części nauczycieli, edukatorów i lokalnych liderów dbających o dziedzictwo polskich Żydów - przez wielu Polaków. Program ten dotyczy pamięci żydowskiej, ale jednocześnie tożsamości polskiej, zniekształconej latami ideologizacji i milczeniem wstydu za zachowanie sąsiadów, a także - w niektórych przypadkach odkrywanych przez nową historiografię - za zachowanie członków własnych rodzin ${ }^{51}$.

W dyskursie nowej historiografii, zainspirowanej debatą wokół Jedwabnego, uwagę badaczy skupia indywidualna i grupowa kolaboracja części społeczeństwa polskiego. W dyskursie edukacji dominują polscy Sprawiedliwi wśród Narodów Świata. Pomiędzy tymi dyskursami brakuje połączeń ${ }^{52}$. FDMN realizuje programy edukacyjne zwią-

46 W Zespole Szkół nr 7 im. Szczepana Bońkowskiego. Obserwacja obejmowała czwarty etap szkolenia prowadzonego w ramach programu „Szkoła Dialogu - Warszawa” przez trenerki Forum Dialogu Między Narodami: Małgorzatę Jastrzębską i Monikę Oszmaniec.

47 Projekt badawczy Jolanty Ambrosewicz-Jacobs realizowany w Centrum Badań Holokaustu Uniwersytetu Jagiellońskiego nad pamięcią o Holokauście w kontekście edukacji formalnej i nieformalnej w Polsce.

48 Na podstawie opisu programu na stronie www.dialog.org.pl.

49 Uczyć się z historii. Doświadczenie totalitaryzmów XX wieku, [online] http://uczyc-sie-z-historii.pl/ $\mathrm{pl} /$ projekty/zobacz/112, $12 \mathrm{~V} 2017$.

50 Cyt. za: M. Eckmann, Przyktady historyczne w edukacji antydyskryminacyjnej, [w:] Różowe trójkąty. Zbrodnie nazistów na osobach homoseksualnych w kontekście edukacji antydyskryminacyjnej, red. K. Remin, Warszawa 2012, s. 91.

51 Zob. B. Engelking, J. Leociak, Getto warszawskie...

52 Zob. J. Ambrosewicz-Jacobs, R. Szuchta, The Intricacies of Education about the Holocaust in Poland. Ten Years after the Jedwabne Debate, What can Polish School Students Learn about the Holocaust in 
zane z podstawami, prerekwizytami pamięci o Zagładzie dążące do włączenia historii i kultury Żydów polskich w historię regionalną i historię Polski. Badania empiryczne Michała Bilewicza ${ }^{53}$ (niektóre z nich obejmują także działania FDMN) zawierają refleksje związane z włączeniem do programów spotkań młodzieży narracji o bohaterach polskich, aby uniknąć postaw obronnych w dyskusjach nad Zagładą w Polsce. Wydaje się, że proponowany krok, dobrze ugruntowany w społecznych teoriach tożsamości, może w przyszłości spowodować zmniejszenie istniejącej rozłączności wymienionych wyżej dyskursów.

Program „Szkoła dialogu - Warszawa” obejmuje cztery spotkania z trenerkami FDMN, w tym dwie wycieczki i dwa warsztaty w szkole. Ich celem jest zapoznanie uczniów z żydowską przeszłością Warszawy oraz stopniowe przygotowanie ich do stworzenia własnego projektu upamiętniającego przedwojenną żydowską społeczność stolicy. Podczas pierwszego spotkania trenerki Forum proponują do wyboru jedną z trzech wycieczek po Warszawie: „Mowa kamieni” (wizyta na cmentarzu żydowskim przy ulicy Okopowej), „Próżna wczoraj i dziš” (spacer po ulicy Próżnej połączony z odwiedzinami w synagodze), „Żydowska Praga”. Celem każdej z nich jest zapoznanie uczniów z podstawowymi pojęciami kultury, religii i tradycji Żydów polskich, a także ukazanie catego bogactwa historii przedwojennej Warszawy ${ }^{54}$. Drugie spotkanie odbywa się w szkole. Warsztat ukazuje zróżnicowanie postaw wobec historii i losu Żydów w Polsce przed II wojną światową i po niej. Uczniowie omawiają postawy zaangażowania i niezaangażowania na przykład w kontekście getta ławkowego czy Holokaustu ${ }^{55}$. Trzecie spotkanie obejmuje inspirowaną grami miejskimi wycieczkę po warszawskim getcie. $W$ czasie spaceru po Śródmieściu i Muranowie uczniowie odkrywaja istniejące ślady zniszczonego miasta oraz poznaja historie zwiazane z miejscami, które już nie istnieja. Trenerzy przekazuja im najważniejsze informacje zwiąane z historia getta. Na zakończenie ogladamy powojenny Muranów, prowokując do nowego spojrzenia na klasyczne już pytania o zasadność budowania i życia na gruzach ${ }^{56}$.

Obserwacja uczestnicząca w ramach projektu badawczego ewaluacji projektów edukacyjnych w Polsce dotyczących pamięci Holokaustu objęła czwarty warsztat, w którym uczniowie rozmawiali na temat różnych form upamiętniania historii. Trenerki Forum wspólnie z uczniami podjęły dyskusję nad oddziaływaniem historii na obecne życie warszawiaków, a następnie przygotowaty uczniów do pracy nad ich wtasnym projektem ${ }^{57}$.

History Classes?, „Intercultural Education” 2014, Vol. 25, nr 4, s. 283-299, [online] http://dx.doi.org/ 10.1080/14675986.2014.926156, 20 II 2016.

53 M. Bilewicz, History as an Obstacle: Impact of Temporal-based Social Categorization on Polish-Jewish Intergroup Contact, „Group Processes \& Intergroup Relations” 2007, Vol. 10, nr 4, s. 551-563, [online] http://dx.doi.org/10.1177/1368430207081540; tenże, Spoteczna pamięć Holokaustu i Auschwitz wśród licealistów: wokót projektu badawczego „Trudne pytania”, [w:] Auschwitz i Holokaust..., s. 23-34.

54 Forum Dialogu, [online] www.dialog.org.pl, 11 II 2016.

55 Tamże.

56 Tamże.

57 Tamże. 
Badany program FDMN starał się skupić na przywracaniu pamięci dzielnicy Warszawy zbudowanej na gruzach getta, na cmentarzu bez ogrodzenia i nagrobków, na gruzach, w których wszak znajdują się szczątki Żydów warszawskich. W obserwowanych warsztatach FDMN wzięło udział 15 uczniów z klas o specjalności wojskowej bezpieczeństwa narodowego z rozszerzonym programem historii, wiedzy o społeczeństwie i języka obcego, obejmującym warsztaty z zakresu ratownictwa medycznego i samoobrony oraz strzelectwa sportowego. Głównym celem spotkania było przygotowanie uczniów do pracy nad ich własnym, wspólnym projektem, który miał dotyczyć różnych miejsc pamięci i różnych sposobów ich upamiętniania. W trakcie pracy uczniów pojawiła się refleksja: Nie wiedziatem, że tyle obiektów $w$ dzisiejszej Warszawie jest na terenie getta. To robi wrażenie, nie wiedziatem tego, świadcząca o istnieniu dużego obszaru niepamięci historii własnego miasta i historii Zagłady.

Engelking i Leociak stwierdzili: Chodzac dzisiaj po obszarze bytego getta, doświadczamy szczególnie paradoksu uobecniania pustki. Doświadczeniu temu towarzyszy swoiste poszerzenie widzenia, podwojenie perspektywy. Oto zaczynamy widzieć to, czego nie widzimy (wyobrażona rekonstrukcje getta); natomiast w jakimś sensie nie widzimy już tego, co widzimy (rzeczywistości postrzeganej tu i teraz). Topografia wspótczesnego Muranowa staje się niejako przezroczysta zastona, która okrywa to, co naprawdę chcemy widzieć. Dokonuje się uobecnienie nieobecności, miejsce-po-getcie urealnia się, a samo getto - owo miasto nieistniejace - zostaje przywrócone pamięci ${ }^{58}$. Z kolei Sidra DeKoven Ezrahi uważa, że powtarzalny charakter spotkań z przesztościa może stać się rodzajem inkantacji, rytuatu - ale może też wskazywać na stale rozwijający się związek z niepogrzebanymi zmartymi $i^{59}$. Wspomniane wcześniej projekty grup Antyschematy i Antyschematy 2 wydają się wskazywać na potrzebę związku, o którym pisze Ezrahi. Projekty te są także przykładem odpowiedzialności obywatelskiej za miejsca w przestrzeni publicznej, do której należą także cmentarze żydowskie, i dbałości o miejsca pochówku mniejszości etnokulturowych na terytorium naszego kraju.

Przykładem braku zrozumienia dla poczucia obywatelskiej odpowiedzialności była reakcja kobiety, która wraz z mężem zwiedzała ohel cadyka Elimelecha w Leżajsku ${ }^{60}$. Według niej, o to miejsce, w jej widzeniu przestrzenie „brudne” i zaniedbane, powinni dbać tylko Żydzi. Fakt, że Żydzi zostali zamordowani, a mieszkający poza granicami Polski religijni Żydzi odbywają pielgrzymki do grobu cadyka tylko sporadycznie, grób zaś znajduje się na terytorium Polski, pozostał poza jej świadomością historyczną. Zwrócenie uwagi na ten fakt wywołało jeszcze większe napięcie.

FDMN określa, iż celem uczniowskiego projektu ma być przypomnienie nieznanej bistorii Żydów warszawskich. Zachęcamy ich do poznawania historii ich wtasnych dzielnic, poszukiwania zapomnianych życiorysów, miejsc, etc. W drugiej kolejności prosimy o to,

58 B. Engelking, J. Leociak, Getto warszawskie..., s. 837.

59 S. DeKoven Ezrahi, Holokaust a zmieniajace się granice sztuki i historii, [w:] Reprezentacje Holokaustu, wybór i oprac. J. Jarniewicz i M. Szuster, Kraków-Warszawa 2014, s. 268, Kolekcja „Literatury na Świecie".

60 Obserwacja własna latem $2014 \mathrm{r}$. 
by przygotowali taka forme upamiętnienia wybranej przez nich historii, jaka wyda im się najbardziej odpowiednia. Może to być wycieczka, happening lub też projekt interneto$w y$. Warto przypomnieć w tym miejscu badania empiryczne Instytutu Badania Opinii Homo Homini z marca 2013 r., które wykazały, że ogólnie uczniowie warszawskich liceów i techników raczej nie są ciekawi kultury żydowskiej, ale spośród propozycji różnych wydarzeń, w których chcieliby uczestniczyć, wybraliby wycieczke po miejscach zwiazanych $z$ historia Żydów w Warszawie ${ }^{61}$.

Trenerzy FDMN pilotują przygotowania do realizacji projektów, udzielając uczniom wsparcia, choć już nie w formie warsztatów. Na zakończenie proszą uczestników o nadesłanie sprawozdania z przeprowadzonego projektu, który bierze udział w organizowanym przez Forum konkursie. Całość programu wieńczy udział laureatów konkursu i przedstawicieli szkół w uroczystej Gali Dialogu.

Uczniowie mogą zatem wziąć udział w projekcie, który sami wybiorą, nadadzą mu treść i formę, a następnie zrealizują. Program FDMN realizuje zatem rekomendacje powstałe w wyniku analizy wyników badań projektu badawczego Agencji Praw Podstawowych Unii Europejskiej (The European Union Agency for Fundamental Rights, FRA), instytucji UE z siedzibą w Wiedniu. Badania przeprowadziła agencja rządowa Szwecji Living History Forum w 2009 r. w oparciu o metody ilościowe i jakościowe obejmujące: sondaż ministrów edukacji i kultury w państwach członkowskich UE, sondaż i wywiady indywidualne wśród dyrektorów wybranych muzeów i miejsc pamięci, zogniskowane wywiady grupowe wśród nauczycieli, przewodników i uczniów oraz obserwację uczestniczącą projektów w muzeach i w miejscach pamięci. Okazało się, że uczniowie mają inne oczekiwania niż edukatorzy czy przewodnicy i nie chcą być przytłoczeni faktami historycznymi recytowanymi w szkołach lub podczas oprowadzania w muzeach czy w byłych obozach koncentracyjnych/obozach śmierci, bez brania pod uwagę ich wieku, poziomu wiedzy, motywacji i zainteresowań. Uczniowie - adresaci działań w miejscach pamięci - chcą być aktywnymi uczestnikami procesu nauczania/ uczenia się i potrzebują uczenia zaangażowanego, biorącego pod uwagę ich potrzeby poznawcze, emocjonalne i gotowość do działania. Podkreślano potrzebę uczenia się poprzez doświadczenie.

O edukacji antydyskryminacyjnej tworzącej pomosty pomiędzy przesztością a życiem i doświadczeniem uczestników pisała Monique Eckmann: Pomosty te mogą być budowane w oparciu o wspólnoty pamięci, jak również poprzez odniesienia terytorialne. Miejscem pamięci nie musi być pomnik. Może być nim ulica, dzielnica, wioska czy granica. Innowacyjne modele edukacyjne zasadzają się na przyktad na wtaczeniu w prace antydyskryminacyjna zapamiętanej historii rdzennej lokalnej wspólnoty $i$ doświadczeń osób nowo przybytych na dany obszar. Najbardziej owocnym tematem dialogu okazuje się czesto podobieństwo podejścia do rozwiąania problemu, a nie podobieństwo doświadczeń wiktymizacji ${ }^{62}$.

61 Informacja nt. badań: [online] http://warszawa.jewish.org.pl/pl/aktualnosci/425-co-warszawscy-uczniowie-wiedza-o-powstaniu-w-getcie-wyniki-badania, 11 II 2016.

62

M. Eckmann, Przyktady historyczne..., s. 93. 
Program FDMN poprzez unikatową strategię pracy z pamięcią nie konfrontował doświadczeń wiktymizacji grup Polaków i Żydów, unikając w ten sposób rywalizacji w cierpieniu, pojawiającej się czasami w trakcie edukacji szkolnej dotyczącej Zagłady. Poczas obserwowanego warsztatu w ramach programu FDMN każda z grup uczniów otrzymała zdjęcia, opisy, opinie ludzi, utwór muzyczny itp. przedstawiające różne sposoby upamiętniania historii: piosenkę o obronie Woli i Ochoty (upamiętnianie Powstania Warszawskiego), happening upamiętniający Zagładę Żydów (upamiętnianie getta warszawskiego), zdjęcia Muzeum Powstania Warszawskiego, Muzeum Historii Żydów Polskich i Zamku Królewskiego w Warszawie ${ }^{63}$.

W trakcie pracy z listą różnych sposobów upamiętniania wydarzeń historycznych prowadzące warsztat trenerki FDMN zachęcały uczniów do wyboru takiej opcji, która mogłaby prowadzić do realizacji własnego projektu kończącego cykl szkolenia ${ }^{64}$. W trakcie dyskusji uczniowie formułowali różne propozycje upamiętniania getta warszawskiego. Rozważano wykorzystanie życiorysu prawdziwej lub fikcyjnej osoby podczas realizacji projektu. W trakcie warsztatu liczba propozycji stopniowo ograniczyła się do następujących: film, happening, wycieczka/warsztaty dla innych, gra miejska, strona internetowa. Ostatecznie uczniowie zaplanowali organizację happeningu typu flash mob („błyskawiczny tłum”), w którym mieli stworzyć żywy mur getta z uczniów zaproszonych do udziału w akcji. Zaplanowano sfilmowanie akcji i zamieszczenie filmu dokumentujaccego jej przebieg w mediach spotecznych. Zaproponowano hasto "Nigdy więcej murów”. Zastanawiano się: "Może to hasto wykrzyczeć?”. Za konieczne uznano przygotowanie ulotki - ogtoszenia informujacego o akcji. Ustalono podziat obowiazków, w tym wskazano grupe, która ma zdobyć mape getta $i$ zdecydować, w którym miejscu będzie ustawiony mur. Wyznaczono osoby odpowiedzialne za zrobienie zdjeć, filmu telefonem komórkowym, poinformowanie o akcji dziennikarzy i ewentualnie ekipy filmowej, umieszczenie relacji z akcji $w$ Internecie ${ }^{65}$.

$\mathrm{Na}$ uwagę zasługuje skuteczność trenerek FDMN w zachęcaniu uczniów do dyskusji, bez sugerowania formy upamiętnienia i kształtu ostatecznego projektu. Trenerki były moderatorkami dyskusji, wskazującymi zalety i trudności propozycji upamiętnienia II wojny światowej oraz Zagłady, a uczniowie mieli realny wpływ na decyzje dotyczące

63 Z raportu Szymona Beźnica: Każda grupa analizowata swój zestaw zdjęć. Uczniów poproszono by każda grupa udzielata odpowiedzi na pytania wypisujac je na duzym arkuszu papieru. Po wpisaniu odpowiedzi na pytania zestaw pomocy wraz z arkuszem udzielonych odpowiedzi byt pozostawiany na miejscu, a grupa przenosita się zgodnie z ruchem wskazówek zegara do kolejnego stanowiska. Tam zapoznawata się z kolejnym zestawem pomocy. W ten sposób każda z grup po pozostawieniu swojego zestawu otrzymywata nowy zestaw, który musiata skomentować dopisując do wypetnionego przez poprzedników arkusza swoje refleksje, uwagi, spostrzeżenia. W ten sposób każda kolejna grupa mogta dopisywaí do arkuszy oprócz refleksji, takze wtasne uwagi, komentarze [manuskrypt].

$64 \mathrm{Z}$ raportu Szymona Beźnica: Ważne wydaje się to, że prowadzace nie narzucaty uczniom sposobu/formy, która powinni wybrać. Dbaty natomiast o to, by poddać dyskusji poszczególne propozycje uczniów [...]. Zaobserwowano, że niektóre grupy miaty duże trudności z opracowaniem planu dziatań. Obserwatorzy zastanawiali się, czy czesść uczniów nie wymagata $w$ tym momencie wsparcia od prowadzacych. Równocześnie jednak samo skonfrontowanie się uczniów z trudem tego zadania wydaje się ważne - uczy, $\dot{z}$ e takie dziatania wymagaja dużej uwagi, zaangażowania i staranności już na etapie przygotowywania [manuskrypt].

65 Raport Szymona Beźnica [manuskrypt]. 
wyboru tematu i środków realizacji projektu, co jest zgodne z oczekiwaniami badanych uczniów wyrażonymi podczas realizacji przytoczonej wcześniej ewaluacji edukacji FRA. Praca trenerek w końcowym - bardzo trudnym etapie warsztatów - byta bardzo dobrze zorganizowana, precyzyjna i skuteczna. Prowadzace potrafity bowiem doprowadzić caty warsztat do finatu, w którym uczniowie stworzyli bardzo konkretny projekt, w ramach którego zostaty rozpisane kolejne dziatania i role poszczególnych uczestników, zostat zaplanowany czas realizacji oraz wskazane trudności i zagrożenia z tym zwiazane $e^{66}$.

Projekt animacji społecznej „Burzymy mury” zrealizowany przez uczniów klas wojskowych CXXV Liceum Ogólnokształcącego im. Waldemara Milewicza z Warszawy zajął II miejsce w konkursie. I miejsce zajął projekt pt. „Shalom Radoszyce” przygotowany przez uczniów Gimnazjum nr $1 \mathrm{im}$. Kazimierza Wielkiego w Radoszycach (woj. świętokrzyskie). Nagrodą był dwudniowy pobyt studyjny w Krakowie i Auschwitz-Birkenau oraz w Kazimierzu Dolnym nad Wisłą. W Kazimierzu Dolnym odbyły się warsztaty trenerów Forum, podczas których uczniowie mogli zapoznać się z historią przedwojennej społeczności żydowskiej w małym miasteczku. Licealiści wzięli udział m.in. w lekcji muzealnej w Kamienicy Celejowskiej, gdzie mogli obejrzeć obrazy ukazujące żydowskich mieszkańców przedwojennego Kazimierza. Ponadto wszystkie szkoły uczestniczące w programie FDMN otrzymują dyplomy i tytuły „Szkoły Dialogu" oraz zestaw książek na temat historii Żydów polskich ${ }^{67}$.

Wyniki badań wskazują, że historia polsko-żydowskich relacji w czasie okupacji dotąd nie została w Polsce w pełni zintegrowana ${ }^{68}$. Istotne jest pytanie: czy wspólna narracja Polaków i Żydów obejmująca II wojnę światową w ogóle jest możliwa? Wydaje się, że wraz ze wzrostem nacisku na ukazywanie polskich Sprawiedliwych bez kontekstu historycznego ich bohaterstwa pogłębiająca się polaryzacja narracji jest nieunikniona. Niemniej jednak powinniśmy wsłuchiwać się w narracje różnych wspólnot pamięci, z definicji rozłącznych, aby w procesie pracy z pamięcią przeszłości (być może kolejnego pokolenia) mogły pojawić się obok siebie głosy z różnych stron, podzielonych granicami narodowymi i państwowymi. Do zintegrowania narracji konieczna jest umiejętność wsłuchiwania się w mikronarracje regionalne, dekonstruujące modelowe wizerunki grup społecznych, a jednocześnie wzbogacające zasoby historii i pamięci. Jednak często wiąże się to z koniecznością przebudowy tożsamości grupowych, co z kolei pociąga za sobą koszty natury psychologicznej ${ }^{69}$.

66 Tamże. Warto byłoby poświęcić uwagę problemowi współpracy z nauczycielami, którzy nie biorą udziału w warsztatach. Wszak to oni pracują z młodzieżą przez cały rok lub przez kilka lat i nie powinni czuć się odizolowani. Takie głosy, niedotyczące obserwowanego warsztatu, pojawiały się zarówno wśród „wyproszonych” nauczycieli, jak i ekspertów zagranicznych.

67 [online] http://www.dialog.org.pl/news_gala_szkoly_dialogu_2010.html; http://www.dialog.org. pl/news_uczniowie_wyroznieni_w_konkursie_szkoly_dialogu_odwiedzili_kazimierz_dolny.html, 11 II 2016.

68 J. Ambrosewicz-Jacobs, Holocaust Consciousness among Polish Youth after the 1989 Collapse of Communism, [w:] Jewish Presence in Absence. The Aftermath of the Holocaust in Poland, 1945-2010, red. F. Tych, M. Adamczyk-Garbowska, Jerusalem 2014, s. 717-757.

69 Por. analizę polityki historycznej w: L.M. Nijakowski, Polska polityka pamięci-esej socjologiczny, Warszawa 2008, Pejzaże Spoteczne. 
Przedstawione w tym tekście warsztaty czy spotkanie córki Sprawiedliwych w Bodzentynie z uczestnikami seminarium dla polskich i szwedzkich nauczycieli, zorganizowanego przez Towarzystwo Dawida Rubinowicza ${ }^{70}$, a także wiele innych projektów edukacyjnych w Polsce nie odsłoniły wszystkich postaw Polaków wobec Żydów w czasie Holokaustu. Córka Sprawiedliwych opowiedziała o odejściu przechowywanego podczas Holokaustu Żyda z domu jej rodziców, wczesnym rankiem, po zakończeniu wojny. Ukrywany w czasie wojny przyjaciel rodziny opuścił dom, gdy było jeszcze ciemno, gdyż wiadomo, jak byto. Nikt spośród obecnych na seminarium nauczycieli nie zapytał: „jak było?". W trakcie spotkań poruszających problematykę Zagłady pewne fakty pozostają nadal w domenie tabu, nawet jeśli są prezentowane przez drugie czy trzecie pokolenie świadków Zagłady. O wielu faktach historycznych związanych z postawami lokalnych społeczności w czasie Zagłady i tuż po niej nadal nie mówi się w ogóle. Kaja Kaźmierska słusznie zauważa, że to wtaśnie problem bycia biernym świadkiem pozostaje gtównym, nieprzepracowanym dotychczas w pamięcipolskiej tematem, $i$ to zarówno w wymiarze pamięci zbiorowej, jak i biograficznej ${ }^{71}$. Dodałabym, iż ten nieprzepracowany temat obejmuje nie tylko bycie biernym świadkiem Zagłady, lecz także przemilczane w lokalnych społeczeństwach niegodne postawy członków własnej zbiorowości narodowej, m.in. donosy na Polaków ukrywających Żydów, mordy, zawłaszczenia własności.

Engelking ${ }^{72}$ i Gross ${ }^{73}$ w swoich badaniach dochodzą do tych samych wniosków: w okupowanej Polsce nie było społecznej aprobaty dla ratowania Żydów. Żydzi znaleźli się poza ramami moralnej odpowiedzialności społeczeństwa polskiego czasów wojny. Spotkania z historią i kulturą Żydów polskich powoli włączają ich do historii naszego kraju, regionu i miasta czy miasteczka, ale rzadko prowadzą do konfrontacji z najciemniejszymi kartami dziejów.

Eckmann twierdzi, iż trudno odkrywa się historię członków własnej grupy jako ofiar zbrodni przeciwko ludzkości, ale jeszcze trudniej jest odkrywać członków własnej grupy jako kolaborantów, sprawców zbrodni, a także jako jej świadków. Pamięć wiktymizacji własnej grupy w przeszłości może dawać poczucie moralnej wyższości, o czym pisał Dan Bar-Tal ${ }^{74}$. Natomiast konfrontacja z grupową (historyczną) odpowiedzialnością własnej grupy za zbrodnie wobec innych może wywołać poczucie wstydu, potencjalnie stanowiące zagrożenie dla tożsamości, o ile nie nastąpi aktywne i świadome wzięcie na siebie odpowiedzialności za przeszłość.

70 Obserwacja uczestnicząca autorki.

71 K. Kaźmierska, Biografia i pamięć..., s. 114. Pamięć biograficzna odnosi się do doświadczeń zgromadzonych w trakcie życia ludzkiego i badana jest poprzez analizę wspomnień, pamiętników, listów, nagranych wywiadów i innych dokumentów osobistych.

72 B. Engelking-Boni, Psychological Distance between Poles and Jews in Nazi-occupied Warsaw, [w:] Contested Memories. Poles and Jews during the Holocaust and its Aftermath, red. J.D. Zimmerman, New Brunswick 2003.

73 J.T. Gross, Upiorna dekada. Eseje o stereotypach na temat Żydów, Polaków, Niemców i komunistów 1939-1948, Kraków 2007.

74 D. Bar-Tal, Sociopsychological Foundation of Intractable Conflicts, „American Behavioral Scientist” 2007, Vol. 50, nr 11, s. 1430-1453, [online] http://dx.doi.org/10.1177/0002764207302462. 
Nauczyciele-eksperci w Polsce nauczają o Zagładzie, gdyż $w$ Sobkowie byli Żydzi; bo jestem w otoczeniu miejsc pamięci [w Brzeszczu]; bo zawsze od studiów wiedziatem, że tak trzeba ${ }^{75}$. Edukatorzy i badacze dyskutują nad rolą muzeów i miejsc pamięci w kontekście praw człowieka, ale w Polsce ten dyskurs nie jest zbyt widoczny, poza konferencjami organizowanymi przez Międzynarodowy Dom Spotkań Młodzieży w Oświęcimiu. Muzea dokumentujące zbrodnie Holokaustu w Polsce (byłe obozy koncentracyjne i/ lub obozy zagłady) mają charakter muzeów historycznych, skupiających uwagę na faktach historycznych i wiedzy. Amerykański model nauczania o Holokauście w kontekście praw człowieka i etyki, a zatem związany ściśle z funkcją wychowawczą, nie jest popularny w Polsce. Wystawy w muzeach są wystawami historycznymi, a oprowadzający po nich przewodnicy rzadko różnicują przekazywane treści w zależności od wieku uczniów. Specyfika polskich wystaw w miejscach pamięci wynika ze specyfiki naszego kraju, będącego epicentrum Zagłady Żydów europejskich, i takiego podejścia oczekuje się od muzeów Zagłady. Uczniowie i dorośli zwiedzający powinni wiedzieć, co wydarzyło się w danym miejscu, ale przekaz historyczny powinien prowadzić do wydobycia wniosków z przeszłości. Natomiast według badanych nauczycieli-ekspertów uczeń w Polsce otrzymuje wiedzę poszufladkowaną, jak w XIX w., a prawa człowieka są przedmiotem uwagi wyłącznie w ramach lekcji wiedzy o społeczeństwie ${ }^{76}$.

Zdarza się, że niektórzy nauczyciele, np. prowadzący historię i wiedzę o społeczeństwie lub uważający, iż konieczne jest łączenie obydwu podejść (m.in. Zbigniew Ryba z Krakowa), „mieszają” obydwie dziedziny i wykorzystują wizytę w miejscach pamięci do edukacji o prawach człowieka, ale nie jest to praktyka powszechna. Najbardziej pożądanym efektem edukacji o Holokauście i edukacji o prawach człowieka jest zaangażowanie młodych ludzi w działania organizacji pozarządowych, w działania obywatelskie na rzecz społeczności lokalnych. Dla badanych nauczycieli nauczanie o Zagładzie ważne jest dlatego, że są zainteresowani przekazem wiedzy, wzbudzeniem przeżycia i rozwojem odpowiedzialności wśród uczniów. Dla nich istotne jest, co z tego wynika dla dzisiejszego świata, i chcą, aby uczniowie byli lepszymi, bardziej odpowiedzialnymi ludźmi. W Sobkowie dba o to nauczycielka matematyki, w Krakowie wiele lat temu działania w tym zakresie prowadziła niezwykle zaangażowana nauczycielka biologii. Arkadiusz Walczak podkreśla wagę włączania uczniów w proces przygotowywania do edukacji i uwzględniania motywacji oraz zainteresowań młodzieży (metoda arkusza zadaniowego pozwalającego na samodzielny wybór programu, metod i aktywności). Przestrzega przed wzbudzaniem szoku i pozostawianiem uczniów z rozbudzonymi emocjami.

Wśród przeszkód i trudności w nauczaniu o Zagładzie w miejscach pamięci nauczyciele wymieniają: brak odpowiedniego przygotowania w trakcie studiów, drwiny ze strony innych nauczycieli, niechętne nastawienie niektórych rodziców, brak wsparcia finansowego i logistycznego, poświęcanie własnego czasu wolnego na wyjazdy.

75 Uwagi wyrażone przez nauczycieli w trakcie zogniskowanego wywiadu grupowego w ramach badań własnych autorki nad pamięcią Zagłady w Krakowie.

76 Uwaga Roberta Szuchty, nauczyciela historii w LXIV LO w Warszawie oraz eksperta Muzeum Historii Żydów Polskich Polin. 
Program FDMN poprzez swój rozmiar i inspirację nauczycieli i uczniów ukazuje, że w kraju, w którym nie było żałoby po zamordowanych Żydach, możliwe jest przezwyciężenie dychotomii Freudowskiej żałoby i melancholii, podobnie jak w wielu innych krajach, także w Niemczech. Ewa Domańska, analizując teorię metahistorii, przywołuje współczesne „kultury melancholii”, skupione na ranach historii, i „kultury żałoby”, skoncentrowane na leczeniu traumy ${ }^{77}$. O ile melancholia oznacza state przeżywanie straty, niemożność przejścia nad nia do porządku dziennego, o tyle praca żatoby pozwala na pogodzenie się ze strata i powrót do normalnego życia ${ }^{78}$ - pisze Jarosław Lubiak, analizując architekturę Muzeum Żydowskiego Daniela Libeskinda w Berlinie. Maria Janion ${ }^{79}$ uważa, że Holokaust był tak wielką masową zbrodnią, iż nie jest możliwe zakończenie żałoby po stracie ponad miliona dzieci żydowskich - koniec żałoby mógłby oznaczać zapomnienie, a Zagłady zapomnieć nie można. Brak końca żałoby nie jest równoznaczny z wezwaniem do melancholii, w moim rozumieniu słów Janion. Melancholia nie jest właściwym rozwiązaniem ze względu na destrukcyjne koszty przeżywania przeszłości, potencjalną regresję do wcześniejszych faz rozwoju i/lub narcystyczne skoncentrowanie na sobie i własnej grupie połączone z brakiem empatii. Lubiak przestrzega zarówno przed melancholią, jak i przed końcem żałoby, która mogłaby doprowadzić do pogodzenia się ze stratą. Przywołuje tu propozycję Libeskinda, by zastąpić prace żatoby praca pamięci $i^{80}$. FDMN jest przykładem konstruktywnej, zaangażowanej i bardzo potrzebnej młodym ludziom „pracy pamięci” nad Zagładą w Polsce.

\section{BIBLIOGRAFIA}

Ambrosewicz-Jacobs J., Holocaust Consciousness among Polish Youth after the 1989 Collapse of Communism, [w:] Jewish Presence in Absence. The Aftermath of the Holocaust in Poland, 1945-2010, red. F. Tych, M. Adamczyk-Garbowska, Jerusalem 2014.

Ambrosewicz-Jacobs J., Meandry pamięci i niepamięci Holokaustu. Konieczność ewaluacji praktyk edukacyjnych woparciu o badania empiryczne, [w:] Nasza szafa. Kultura, edukacja, animacja. Czerwiec-listopad 2014, red. A. Dąbrowicz, B. Muras, Łódź 2014.

Ambrosewicz-Jacobs J., Postpamięć Zagtady w Polsce. Dobre praktyki w edukacji nieformalnej, [w:] Miejsce po - miejsce bez. Konferencja zorganizowana przez Muzeum Historyczne Miasta Krakowa, 9-11 kwietnia 2015 roku w ramach wydarzenia Pamiętaj z nami, Kraków 2015.

Ambrosewicz-Jacobs J., Büttner E., Isolated Islands? Memory of the Holocaust in Formal and Informal Education. The Case Study of Post-Communist Poland, „Politeja” 2014, Vol. 11, nr 27, [online] http://dx.doi.org/10.12797/politeja.11.2014.27.04.

77 Cyt. za: J. Dąbrowska-Zydroń, Pamięć i kontrpamięć w przekazie artystycznym. Wokót prac Christiana Boltanskiego, [w:] Pamięć Shoah. Kulturowe reprezentacje i praktyki upamiętnienia, red. T. Majewski, A. Zeidler-Janiszewska, współpr. red. M. Wójcik, Łódź 2009, s. 685.

78 J. Lubiak, O nowy ksztatt pamięci. Muzeum Żydowskie w Berlinie, [w:] Pamięć Shoah..., s. 623.

79 Opowiadać o ludzkim cierpieniu. Andrzej Franaszek w rozmowie z profesor Maria Janion, „Tygodnik Powszechny" 2007, nr 6, s. 8.

80 J. Lubiak, O nowy ksztatt pamięci... 
Ambrosewicz-Jacobs J., Szuchta R., The Intricacies of Education about the Holocaust in Poland. Ten Years after the Jedwabne Debate, What can Polish School Students Learn about the Holocaust in History Classes?, „Intercultural Education” 2014, Vol. 25, nr 4, [online] http:// dx.doi.org/10.1080/14675986.2014.926156.

Applebaum A., Gutag, przeł. J. Urbański, Warszawa 2013.

Assmann A., Europe: A Community of Memory? Twientieth Annual Lecture of the GHI, „GHI Bulletin” 2007, nr 40, [online] https://www.ghi-dc.org/fileadmin/user_upload/GHI_Washington/Publications/Bulletin40/011.pdf.

Assmann A., Response to Peter Novick, „GHI Bulletin” 2007, nr 40, [online] https://www.ghi-dc.org/fileadmin/user_upload/GHI_Washington/Publications/Bulletin40/033.pdf.

Audiowalk Gusen, [online] http://audioweg.gusen.org/en/.

Auschwitz i Holokaust. Dylematy i wyzwania polskiej edukacji, red. P. Trojański, Oświęcim 2008.

Bar-Tal D., Sociopsychological Foundation of Intractable Conflicts, „American Behavioral Scientist" 2007, Vol. 50, nr 11, [online] http://dx.doi.org/10.1177/0002764207302462.

Bilewicz M., History as an Obstacle: Impact of Temporal-based Social Categorization on Polish-Jewish Intergroup Contact, „Group Processes \& Intergroup Relations” 2007, Vol. 10, nr 4, [online] http://dx.doi.org/10.1177/1368430207081540.

Bilewicz M., Spoteczna pamięć Holokaustu i Auschwitz wśród licealistów: wokót projektu badawczego „Trudne pytania”, [w:] Auschwitz i Holokaust. Dylematy i wyzwania polskiej edukacji, red. P. Trojański, Oświęcim 2008.

Błoński J., Biedni Polacy patrza na getto, „Tygodnik Powszechny” 1987, nr 2.

Cohen E.H., Identity and Pedagogy. Shoah Education in Israeli State Schools, Boston 2013.

Dąbrowska-Zydroń J., Pamięć i kontrpamięć w przekazie artystycznym. Wokót prac Christiana Boltanskiego, [w:] Pamięć Shoah. Kulturowe reprezentacje i praktyki upamiętnienia, red. T. Majewski, A. Zeidler-Janiszewska, współpr. red. M. Wójcik, Łódź 2009.

DeKoven Ezrahi S., Holokaust a zmieniające się granice sztuki i historii, [w:] Reprezentacje holokaustu, wybór i oprac. J. Jarniewicz, M. Szuster, Kraków-Warszawa 2014, Kolekcja „Literatury na Świecie”.

Desbois P., The Holocaust by Bullets. A Priest's Journey to Uncover the Truth Behind the Murder of 1.5 Million Jews, New York 2008.

Eckmann M., Przyktady historyczne w edukacji antydyskryminacyjnej, [w:] Różowe trójkaty. Zbrodnie nazistów na osobach homoseksualnych w kontekście edukacji antydyskryminacyjnej, red. K. Remin, Warszawa 2012.

Engelking B., Leociak J., Getto warszawskie. Przewodnik po nieistniejącym mieście, wyd. II zm., popr. i rozsz., Warszawa 2013.

Engelking-Boni B., Psychological Distance between Poles and Jews in Nazi-occupied Warsaw, [w:] Contested Memories. Poles and Jews during the Holocaust and its Aftermath, red. J.D. Zimmerman, New Brunswick 2003.

Foucault M., Language, Counter-Memory, Practice. Selected Essays and Interviews, przeł. D.F. Bouchard, S. Simon, Ithaca 1977.

Gross J.T., Sąsiedzi. Historia zagtady żydowskiego miasteczka, Sejny 2000.

Gross J.T., Strach. Antysemityzm w Polsce tuż po wojnie. Historia moralnej zapaści, Kraków 2008. 
Gross J.T., Upiorna dekada. Eseje o stereotypach na temat Żydów, Polaków, Niemców i komunistów 1939-1948, Kraków 2007.

Gross J.T., Grudzińska-Gross I., Ztote żniwa. Rzecz o tym, co się dziato na obrzeżach zagtady Żydów, Kraków 2011.

Gross M., To Teach the Holocaust in Poland: Understanding Teachers' Motivations to Engage the Painful Past, „Intercultural Education” 2013, vol. 24, nr 1-2, [online] http://doi.org/10. 1080/14675986.2013.773126.

Harris Interactive and IMAS International Conduct Thirteen-Country Survey in Remembrance of $60^{\text {th }}$ Anniversary of World War II, [online] http://www.prnewswire.com/news-releases/harris-interactive-and-imas-international-conduct-thirteen-country-survey-in-remembrance-of-60th-anniversary-of-world-war-ii-54587947.html.

Hirsch M., Family Frames. Photography, Narrative and Postmemory, Cambridge 1997.

Holocaust Education in a Global Context, red. K. Fracapane, M. Haß, współpr. Topography of Terror Foundation, Berlin-Paris 2014.

Janicka E., Pamięć i tożsamość w przestrzeni dawnego getta warszawskiego, „Herito” 2013, nr 13. Jędruszczak B., Młynarczyk W., Szuchta R., Wybór źródet do nauczania o zagtadzie Żydów na okupowanych ziemiach polskich. Ćwiczenia, Warszawa 2010.

Kaźmierska K., Biografia i pamięć. Na przyktadzie pokoleniowego doświadczenia ocalonych z zagtady, Kraków 2008.

Kosiewski P., Zaznaczyć miejsce. Rozmowa z Tomaszem Lecem, Opór i Zagtada. Żydzi w Polsce. Rok 1943, „Tygodnik Powszechny” [dodatek] 2013, nr 16.

Kranz T., Pedagogika pamięci jako forma edukacji muzealnej, [w:] Wizyty edukacyjne w Państwowym Muzeum na Majdanku. Poradnik dla nauczycieli, red. T. Kranz, Lublin 2012.

Kucia M., Optymistyczne dane - niepokojace pytania - radykalne wnioski, [w:] Auschwitz i Holokaust. Dylematy i wyzwania polskiej edukacji, red. P. Trojański, Oświęcim 2008.

Lentin R., Introduction: Postmemory, Unsayability and the Return of the Auschwitz Code, [w:] Re-Presenting the Shoah for the Twenty-First Century, red. R. Lentin, New York 2004.

Lubiak J., O nowy ksztatt pamięci. Muzeum Żydowskie w Berlinie, [w:] Pamięć Shoah. Kulturowe reprezentacje i praktyki upamiętnienia, red. T. Majewski, A. Zeidler-Janiszewska, współpr. red. M. Wójcik, Łódź 2009.

Newsletter Forum Dialogu Między Narodami, 2 II 2016, [online] http://www.dialog.org.pl/ news_gala_szkoly_dialogu_2010.html.

Nijakowski L.M., Polska polityka pamięci - esej socjologiczny, Warszawa 2008, Pejzaże Spoteczne.

Novick P., Comments on Aleida Assmann's Lecture, „GHI Bulletin” 2007, nr 40, [online] https://www.ghi-dc.org/fileadmin/user_upload/GHI_Washington/Publications/Bulletin40/027.pdf.

Pentor, Duma i wstyd. Wielkie badanie pamięci zbiorowej, „Gazeta Wyborcza” 2004, 17 IX.

Research in Teaching and Learning about the Holocaust. A Dialogue Beyond Borders, red. M. Eckmann, D. Stevick, J. Ambrosewicz-Jacobs, Berlin 2017, IHRA Series, 3.

Steinlauf M.C., Pamięć nieprzyswojona. Polska pamięć zagtady, przeł. A. Tomaszewska, Warszawa 2001.

Szacka B., Czas przeszty, pamięć, mit, Warszawa 2006, Wspótczesne Spoteczeństwo Polskie Wobec Przesztości, 3. 
Szpociński A., Pamięćprzesztości i strategie legitymizacyjne, [w:] Pamięć. Rejestry i terytoria. Memory. Registers and Territories, red. P. Orłowska, przeł. J. Taylor-Kucia, Kraków 2013.

Szurek J.-Ch., Między historia a pamięcią: polski świadek Zagtady, [w:] Zagtada Żydów. Pamięć narodowa a pisanie historii $w$ Polsce $i$ we Francji. Wybrane materiaty $z$ kolokwium polsko-francuskiego, Lublin 22-23 stycznia 2004, red. B. Engelking i in., Lublin 2006.

Todorov T., Les Abus de la Mémoire, Paris 1995.

Traba R., Historia - przestrzeń dialogu, Warszawa 2006.

Trojański P., Edukacja o Holokauście w Polsce. Próba krytycznego bilansu, [w:] Edukacja muzealna w Polsce. Aspekty, konteksty, ujęcia, red. W. Wysok, A. Stępnik, Lublin 2013.

Trudne pytania w dialogu polsko-żydowskim, Warszawa 2006.

Ubertowska A., Literatura i pamięć o Zagtadzie: Archiwa, ślady, krypty, [w:] Stosowność i forma. Jak opowiadać o Zagtadzie?, red. M. Głowiński i in., Kraków 2006.

Uczyć się z historii. Doświadczenie totalitaryzmów XX wieku, [online] http://uczyc-sie-z-historii.pl/pl/projekty/zobacz/112.

Wybór źródet do nauczania o zagtadzie Żydów na okupowanych ziemiach polskich, wybór i oprac. zespół pod kierunkiem A. Skibińskiej i R. Szuchty, wstęp i słownik terminów R. Szuchta, wybór oprac. i wstęp do rozdz. Świadectwa literackie W. Młynarczyk, Warszawa 2010.

Dr hab. Jolanta AMBROSEWICZ-JACOBS, kulturoznawca, adiunkt w Katedrze UNESCO ds. Edukacji o Holokauście w Instytucie Europeistyki Uniwersytetu Jagiellońskiego w Krakowie. Stypendystka Pew w Centrum Praw Człowieka Uniwersytetu Columbia w Nowym Jorku oraz DAAD w Domu Konferencji Wannsee w Berlinie. W latach 2011-2012 Ina Levine Invitational Scholar w Center for Advanced Holocaust Studies at United States Holocaust Memorial Museum. Laureatka Nagrody im. Ireny Sendlerowej w 2012 roku (wspólnie z Marią Janion) ustanowionej przez Fundację Taubego na rzecz Życia i Kultury Żydowskiej. Wybrane publikacje: Me - Us - Them. Ethnic Prejudices and Alternative Methods of Education: The Case of Poland (2003), Tolerancja. Jak uczyć siebie i innych $(2003,2004)$, Dlaczego należy uczyć o Holokauście? (red. J. Ambrosewicz-Jacobs i L. Hońdo; 2003, 2004, 2005), Jak uczyć o Holokauście i Auschwitz. Materiaty dydaktyczne (red. J. Ambrosewicz-Jacobs, K. Oleksy i P. Trojański; 2007), Pamięć. Świadomość. Odpowiedzialność. Remembrance. Awareness, Responsibility (red. J. Ambrosewicz-Jacobs, K. Oleksy; 2008), The Holocaust: Voices of Scholars (red. J. Ambrosewicz-Jacobs; 2009). 